\title{
Eyelid aging: pathophysiology and clinical management
}

\section{Envelhecimento palpebral: fisiopatologia e considerações clínicas}

Renato Wendell Damasceno ${ }^{1,2}$, Georgia Avgitidou ${ }^{3}$, Rubens Belfort Jr. ${ }^{4}$, Paulo Elias Correa Dantas ${ }^{5}$, Leonard M. Holbach ${ }^{6}$, Ludwig M. Heindl ${ }^{3}$

\begin{abstract}
Life expectancy is increasing in most countries. With increasing age, many individuals may develop involutional ophthalmic diseases, such as eyelid aging. Dermatochalasis, ptosis, ectropion, and entropion are common disorders in middle-aged and older adults. This review outlines the pathophysiology and clinical management of these involutional eyelid disorders. Recently, a decrease in elastic fibers with ultrastructural abnormalities and an overexpression of elastin-degrading enzymes have been demonstrated in involutional ectropion and entropion. This may be the consequence of local ischemia, inflammation, and/or chronic mechanical stress. Eyelid aging with progressive loss of tone and laxity may affect the ocular surface and adnexal tissues, resulting in different clinical symptoms and signs. Surgical management depends on the appropriate correction of the underlying anatomical defect.
\end{abstract}

Keywords: Aging; Eyelid; Eyelid diseases; Ectropion; Entropion; Extracellular matrix; Elastin; Matrix metalloproteinases

\section{RESUMO}

A expectativa de vida está aumentando na maioria dos países. Com o envelhecimento, muitos indivíduos desenvolverão doenças oculares crônicas e involucionais, tais como o envelhecimento palpebral. Dermatocálase, ptose, ectrópio e entrópio são doenças frequentes em adultos e idosos. Esta revisão destaca a fisiopatologia e a clínica de doenças palpebrais involucionais. Recentemente, uma diminuição de fibras elásticas com anormalidades ultraestruturais e um aumento de enzimas degradantes de elastina foram demonstrados em ectrópio e entrópio involucionais. Isto pode ser consequência de isquemia local, inflamação elou estresse mecânico crônico. O envelhecimento palpebral com perda progressiva de tônus e flacidez pode afetar a superfície ocular e os anexos oculares, resultando em sinais e sintomas clínicos diferentes. O tratamento cirúrgico depende da correção apropriada do defeito anatômico subjacente.

Descritores: Envelhecimento; Pálpebras;Doenças palpebrais; Ectrópio; Entrópio; Matriz extracelular; Elastina; Metaloproteinase da matriz

\section{INTRODUCTION}

As life expectancy increases worldwide (about 600 million people are aged 60 years and older)(1), involutional and chronic eye diseases are becoming increasingly important in the spectrum of ophthalmological diseases. The involutional changes that result in eyelid pathology include ectropion and entropion, dermatochalasis, and aponeurotic ptosis.

The advanced loss of laxity and tone, which is the characterizing feature of the aging of ocular adnexal tissue, results in sagging eyelids ${ }^{(2-5)}$. Genetic causation, which cannot be modified by human behavior, is a part of the intrinsic aging mechanism ${ }^{(6,7)}$. However, extrinsic aging can be caused by parameters, such as alcohol use, chronic exposure to sunlight, smoking, and nutrition ${ }^{(6,7)}$.

The only treatment option for involutional eyelid malposition is surgical adjustment of the underlying anatomical involutional disorder. This review underlines the current pathophysiology and clinical management.

\section{Epidemiology}

Dermatochalasis, ptosis, ectropion, and entropion are common disorders in middle-aged and older adults. The overall prevalence of sagging eyelids among individuals aged $\geqq 45$ years is reported to be $16 \%$, comprising $19 \%$ of men and $14 \%$ of women ${ }^{(8)}$. Two large epide- miologic studies - the Rotterdam study and the Twins UK study-dealt with the prevalence and risk factors for sagging eyelids ${ }^{(9)}$. Two large study populations were chosen for these studies: The Rotterdam study included 5578 individuals of North European origin with an average age of 67 years living in the periphery of Rotterdam and the UK twins study involved 2186 twins with an average age of 53 years living in Great Britain ${ }^{(8)}$. By studying these populations, many non-genetic risk factors for sagging eyelids could be discerned, including age, high body mass index, lighter skin color, smoking, male gender, and heritability ${ }^{(8)}$. Genetic analysis showed the C allele of rs11876749 on chromosome 18 to be a defensive risk factor for sagging eyelids ${ }^{(8)}$.

Sufficient data are not yet available regarding the incidence of ptosis ${ }^{(9,10)}$. The most prominent underlying reason for acquired ptosis is aponeurosis ${ }^{(11)}$

The prevalence of involutional ectropion seems to be similar to that of involutional entropion ${ }^{(12)}$. The literature suggests that the prevalence of ectropion is about $4 \%$ in patients older than 49 years, not differing among the different ectropion forms or regarding the underlying etiology ${ }^{(12,13)}$. This involutional malformation is the most common form of ectropion and entropion ${ }^{(14)}$. Males are more often affected by involutional ectropion ${ }^{(12)}$. In contrast, involutional entropion is more often seen in women ${ }^{(12)}$. This gender difference is caused by the difference in tarsal plate size and axial ocular globe projection between
Submitted for publication: February 9, 2015

Accepted for publication: July 31, 2015

Universidade Estadual de Ciências da Saúde de Alagoas, Maceió, AL, Brazil.

2 Centro de Reabilitação Visual, Maceió, AL, Brazil.

${ }^{3}$ Department of Ophthalmology, University of Cologne, Cologne, Germany.

${ }^{4}$ Department of Ophthalmology, Escola Paulista de Medicina (EPM), Universidade Federal de São

Paulo (UNIFESP), São Paulo, SP, Brazil.

Department of Ophthalmology, Santa Casa de Misericórdia de São Paulo, São Paulo, SP, Brazil.

${ }^{6}$ Department of Ophthalmology, University of Erlangen-Nuremberg, Erlangen, Germany.
Funding: No specific financial support was available for this study.

Disclosure of potential conflicts of interest: None of the authors have any potential conflict of interest to disclose.

Corresponding author: Renato W. Damasceno. Centro de Reabilitação Visual - Rua Dr. Albino Magalhães, 135 - Maceió, AL - 57050-080 - Brazil - E-mail: renatowendell@hotmail.com 
the two genders $(12,15,16)$. The involutional forms of ectropion and entropion affect whites more often than blacks ${ }^{(17,18)}$. The prevalence of involutional ectropion and entropion increases with the patient's age ${ }^{(12)}$, which is the logical order for involutional malformations to increase with age ${ }^{(13)}$.

\section{Pathogenesis and pathological findings}

The advanced loss of laxity and tone, which is a characteristic feature of aging ocular adnexal tissue, results in sagging eyelids ${ }^{(2-5)}$. Histologic examination of dermatochalasis specimens shows an increased number and dilation of lymphatic vessels in conjunction with widely spaced collagen bundles. A reduction in elastic fibers, which are essential components of the function and structure of the lymphatic system, has also been demonstrated ${ }^{(5,19)}$. The pathogenesis of dermatochalasis may begin with subclinical inflammation and lead to elastolysis and secondary lymphostasis ${ }^{(5,9)}$.

The most common pathogenesis for ptosis is aponeurotic ptosis ${ }^{(12)}$. The levator muscle starts thinning and begins to lose muscle tone. As a result, it is not able to keep the upper lid in the correct position above the eye and ptosis ensues ${ }^{(9)}$. Disinsertion or dehiscence of the levator aponeurosis can also cause ptosis ${ }^{(9)}$. Other risk factors for ptosis include intraocular surgery and chronic inflammatory diseases that disinsert the levator aponeurosis from the tarsal plate ${ }^{(9)}$. In conclusion, patients wearing hard contact lens or suffering from eye infections and those having undergone ocular surgery or (peri-)ocular trauma are more likely to develop involutional ptosis ${ }^{(9)}$. Considering the underlying pathogenesis of age-related aponeurotic blepharoptosis, a recent histopathological study revealed that oxidative stress of the levator aponeurosis also plays a potential role in its pathogenesis ${ }^{(20)}$.

The lateral laxity of the canthal tendon is the most important reason for the appearance of involutional ectropion and entropion. Laxity of the medial canthal tendon as well as false insertion of the lower retractors are also conductive parameters ${ }^{(12,21-26)}$. Age-related decrease and atrophy of the orbital fat as well as the relaxation of the ligamentous support lead to an increasing eyelid-globe disparity that again compounds eyelid laxity $(9,16)$.

Some studies reported the presence of abnormal elastic fibers in involutional ectropion and entropion; however, they did not measure them nor did they address the possible reasons for the abnormal fibers ${ }^{(21,22)}$. Damasceno et al. revealed a decrease in elastic fibers in the pretarsal orbicularis oculi muscle, in the tarsal stroma, and in the eyelid skin in patients suffering from age-related involutional ectropion and entropion ${ }^{(27)}$. Ultrastructural abnormalities of the elastic fibers were also observed. These findings have been documented in other diseases as well, such as cutis laxa, Ehlers-Danlos syndrome, floppy eyelid syndrome, Marfan syndrome, Menkes' syndrome, progressive systemic sclerosis, and pseudoxanthoma elasticum ${ }^{(28-30)}$. Ultrastructural changes in the elastic fibers of the eyelid in patients suffering from involutional ectropion and entropion may result from a primary defect in the formation of elastin or from the secondary enzymatic degradation of properly formed fibers ${ }^{(27,30)}$. Damasceno et al. have demonstrated an overexpression of elastolytic enzymes, such as MMP-9, MMP-7, and MMP-2(27,30). It remains speculative to reflect whether raised elastolytic activity can result in decreased numbers and structural abnormalities of elastic fibers ${ }^{(30)}$. However, raised elastolytic activity is already known to be responsible for the loss of elastic fibers of the skin in the acquired form of cutis laxa ${ }^{(29,30)}$. MMP-2, one of the most powerful elastolytic enzymes, is released during ischemia and inflammatory processes ${ }^{(30-32)}$. MMP-7 and MMP-9 are responsible for the degradation of the elastic fibers in anetoderma, floppy eyelid syndrome, and mid-dermal elastosis ${ }^{(30,33,34)}$. These elastin-degrading enzymes are released during ischemia, inflammation, and chronic mechanical irritation ${ }^{(30,35-37)}$. Overexpression of elastin-degrading enzymes in involutional ectropion and entropion specimens may be the consequence of local ischemia, inflammation, and/or chronic mechanical stress ${ }^{(27)}$. Increased expression of MMP-2, MMP-7, and MMP-9 is also observed in areas with and without inflammatory cell infiltration and may be induced by a local ischemic lesion, inflammation, and/or repeated mechanical trauma ${ }^{(27,38)}$. Atherosclerosis of the eyelid marginal artery, reported in patients with involutional ectropion ${ }^{(21)}$, chronic blepharitis, and eye rubbing, is an example of such predisposing factors(27). Additionally, upregulation of MMP-7 and MMP-9 by mechanical stress has been demonstrated ${ }^{(30,35,37)}$. In involutional ectropion and entropion, there is a significant negative correlation between horizontal eyelid laxity and extracellular matrix components, including collagen and elastic fibers, so that both components are affected by degenera-

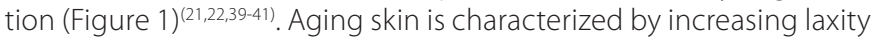
and decreasing numbers of collagen and elastic fibers ${ }^{(39,42-44)}$. Collagen and elastic fibers are essential components of the extracellular matrix of the eyelid and are responsible for its function ${ }^{(6,7,39)}$. Collagen fibers are liable for the tensile strength; elastic fibers responsible for the flexibility and resiliency ${ }^{(6,7,39)}$.

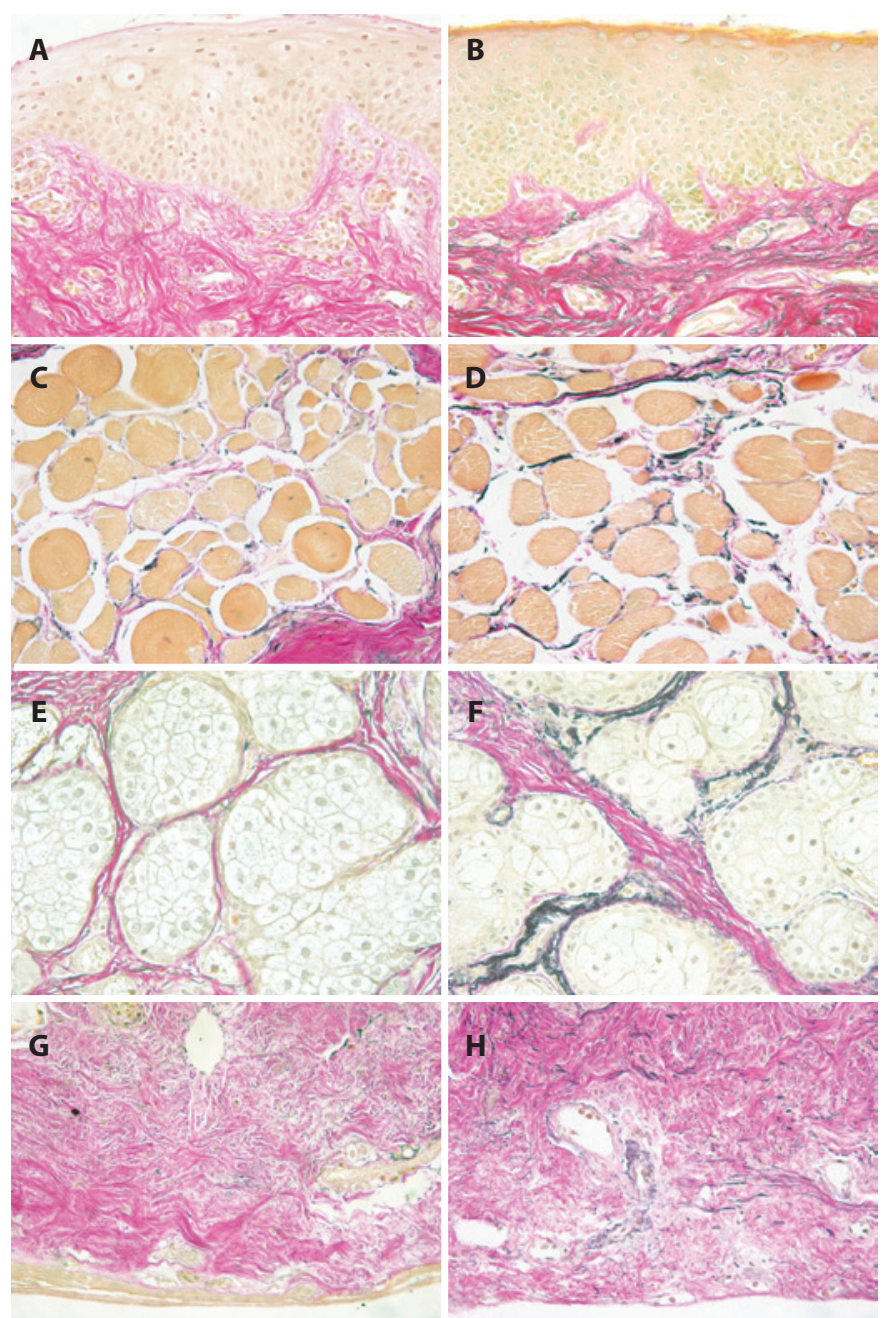

Figure 1. Histopathologic sections of full-thickness eyelid specimens obtained from the lateral lower eyelid of a 65 -year-old male patient with involutional ectropion and lateral canthal tendon laxity $(A, C, E, G)$ and controls $(B, D, F, H)$ stained using van Gieson's method for elastic fibers. Elastic fibers appear dark-brown, collagen fibers appear red (Original magnification, 400×). A, B, C, D, Anterior lamellar regions with eyelid skin and pretarsal orbicularis oculi muscle show a nearly complete absence of elastic fibers in involutional ectropion (A, C) compared with control tissue $(B, D) . E, F, G, H$, Posterior lamellar regions with perimeibomian tarsal stroma and intermeibomian tarsal stroma reveal a marked reduction of elastic fibers in involutional ectropion $(E, G)$ compared with control tissue (F, H). (Modified from Reference 42). 
In general, two different mechanisms are important for skin aging: the intrinsic and extrinsic systems ${ }^{(6)}$. Genetic causation, which cannot be modified by human behavior, is part of the intrinsic aging mechanism ${ }^{(6,7)}$. Conversely, extrinsic aging can be altered by parameters like alcohol use, chronic exposure to sunlight, smoking, and nutrition deficit ${ }^{(6,7)}$. The most important parameter contributing to $80 \%$ of skin aging skin aging appears to be sun exposure ${ }^{(45)}$. Long-term exposure to extrinsic aging parameters or voluntary exposure within a period of time can also cause preterm skin aging ${ }^{(45)}$.

\section{Clinical findings}

The pathological processes of eyelid aging with advanced loss of laxity and tone may affect the ocular surface and adnexal tissues, resulting in different clinical symptoms and signs.

Dermatochalasis is an excess of skin weighed down by the effect of gravity. Patients with upper eyelid dermatochalasis often suffer from drooping eyelids, blurred vision, increased tearing or reduced peripheral vision in the upper hemisphere, as well as tired or sleepy appearing eyes ${ }^{(9)}$. In addition to simple folds of loose skin, there is usually a presence of underlying orbital fat, which is often restricted to the medial fat pad in the upper lid $^{(46)}$. A pseudoptosis may be induced by the increased weight of the tissue, but a true ptosis may also be present ${ }^{(46)}$. Both the upper eyelid and, rarely, the lower eyelid can be involved in dermatochalasis. Long-standing massive dermatochalasis of the lower eyelid may lead to ectropion; however, despite all these possible functional symptoms, most of the patients will be more bothered by the cosmetic appearance of the eyelids.

A moderate ptosis may cause symptoms similar to those of upper eyelid dermatochalasis. Severe ptosis decreases the visual field so that patients need to raise their eyebrows or eyelids with their fingers or tilt their heads back at the neck to see from under the sagging eyelids ${ }^{(9)}$. Only these maneuvers will make everyday activities, such as driving, climbing stairs, or reading possible $e^{(9)}$. Side effects of raising the eyebrow include headache, painful eyes, and an odd "surprised" appearance $e^{(9)}$. The evaluation of levator function allows the correct classification of ptosis severity, which is the basis for the selection of the therapeutic option ${ }^{(47)}$. Levator function can be determined by measuring the amplitude of the upper lid from extreme down gaze to extreme up gaze ${ }^{(47)}$. Using this measure, levator function can be classified as (1) good levator function, when the excursion amounts to $8 \mathrm{~mm}$, (2) moderate, when the excursion amounts to 5-7 mm, and (3) poor, when the excursion amounts $4 \mathrm{~mm}^{(47)}$. Typical features of aponeurotic blepharoptosis include good levator function, deep upper lid sulcus, and excessive skin wrinkles ${ }^{(2)}$. Blepharoptosis gets worse in the evening as a result of tired Muller's muscles which antagonize ptosis throughout the day ${ }^{(2,46)}$.

Ocular surface and eyelid abnormalities associated with involution ectropion include lateral canthal tendon laxity (with an incidence of $80 \%)$, dry eye (52\%), chronic blepharitis (43\%), chronic conjunctivitis (40\%), lower retractor laxity (40\%), superficial punctate keratopathy (29\%), and medial canthal tendon laxity (18\%). ${ }^{(18)}$ The ocular surface and pathologic eyelid findings associated with involutional entropion include lateral canthal tendon laxity (78\%), dry eye (72\%), superficial punctate keratopathy (62\%), lower retractor laxity (53\%), chronic blepharitis (49\%), chronic conjunctivitis (23\%), and medial canthal tendon laxity $(15 \%)^{(12)}$. Patients with involutional ectropion more often suffer from chronic conjunctivitis ${ }^{(12)}$ and have a higher axial ocular globe projection ${ }^{(12,16)}$. However, dry eye syndrome, superficial punctate keratopathy, and laxity of the lower retractor are more common in patients with involutional entropion ${ }^{(12,16)}$. No differences can be seen between ectropion and entropion regarding the frequency of chronic blepharitis, lateral or medial canthal tendon laxity ${ }^{(21,24,26)}$. The most common etiologic factor for involutional ectropion and entropion of the lower eyelid is lateral canthal tendon laxity ${ }^{(24-27,29)}$.

\section{SURGiCAL MANAGEMENT}

Because of the anatomical conditions and pathogenesis of involutional eyelid malposition, favorable surgical management is possible ${ }^{(3,10,47)}$. Dermatochalasis can be corrected through upper and lower eyelid blepharoplasty. After marking the area of excessive skin, the surgeon begins the upper blepharoplasty with an incision on the lid crease and finishes with an incision along the marked area of excessive skin. The surgeon should prepare and separate a flap including both skin an orbicularis muscle ${ }^{(48)}$ to avoid excessive bleeding. A new lid crease can be created by suturing the levator aponeurosis to the orbicularis muscle ${ }^{(48)}$.

Involutional ectropion can be treated by shortening or tightening the underlying anatomical structures ${ }^{(47)}$. A modified Bick procedure can be performed when the ectropion is located centrally. This procedure requires a pentagonal excision of full thickness, followed by direct closure $6 \mathrm{~mm}$ in from the lateral canthus ${ }^{(47)}$. A lateral tarsal strip procedure can be performed for a laterally located ectropion ${ }^{(47)}$. The nasolacrimal system needs special protection during functional reposition of a medial ectropion ${ }^{(47)}$.

Surgical methods for treating entropion incorporate transverse lid split, horizontal shortening, everting sutures, and retractor application $^{(47)}$

Surgical treatment of aponeurotic ptosis depends on levator function ${ }^{(47)}$. To treat the disinsertion of the levator aponeurosis, an aponeurosis advancement is usually performed while good levator function still exists ${ }^{(47)}$.

\section{REFERENCES}

1. World health statistics 2009. Geneva:World Health Organization; 2009.[cited 2014 Jun 21]. Available from: http://www.who.int/gho/publications/world_health_statistics/ EN_WHSO9_Full.pdf

2. Tyers A. Aging lids: A review. Orbit. 1984;3(2):75-80

3. Matayoshi S, Burnier SV, Sant'Anna AE, Soares EJ. Plástica ocular: triquiase, entrópio, ectrópio, simbléfaro, transplante de glándulas salivares. In: Gomes JA, editor. Superficie ocular: córnea, limbo, conjunctiva e filme lacrimal. Rio de Janeiro: Cultura Médica; 2006. p.347-75.

4. Guinot C, Malvy DJ, Ambroisine L, Latreille J, Mauger E, Tenenhaus M, et al. Relative contribution of intrinsic vs extrinsic factors to skin aging as determined by a validated skin age score. Arch Dermatol. 2002;138(11):1454-60.

5. Nagi KS, Carlson JA, Wladis EJ. Histologic assessment of dermatochalasis: elastolysis and lymphostasis are fundamental and interrelated findings. Ophthalmology. 2011; 118(6):1205-10

6. Montes GS. Structural biology of the fibres of the collagenous and elastic systems Cell Biol. Int. 1996;20(1):15-27.

7. Kielty CM, Sherratt MJ, Shuttleworth CA. Elastic fibres. J Cell Sci. 2002;115(Pt 14):2817-28.

8. Jacobs LC, Liu F, Bleyen I, Gunn DA, Hofman A, Klaver CC, et al. Intrinsic and extrinsic risk factors for sagging eyelids. JAMA Dermatol. 2014;150(8):836-43.

9. Finsterer J. Ptosis: causes, presentation, and management. Aesthetic Plast Surg. 2003; 27(3):193-204

10. Cruz AA. Blefaroptoses e retrações palpebrais. 5a ed. Rio de Janeiro: Cultura Médica; 1998.

11. Lim JM, Hou JH, Singa RM, Aakalu VK, Setabutr P. Relative incidence of blepharoptosis subtypes in an oculoplastics practice at a tertiary care center. Orbit. 2013;32(4):231-4.

12. Damasceno RW, Osaki MH, Dantas PE, Belfort R Jr. Involutional entropion and ectropion of the lower eyelid: prevalence and associated risk factors in the elderly population. Ophthal Plast Reconstr Surg. 2011;27(5):317-20.

13. Mitchell P, Hinchcliffe P, Wang JJ, Rochtchina E, Foran S. Prevalence and associations with ectropion in an older population: the Blue Mountains Eye Study. Clin Experiment Ophthalmol. 2001;29(3):108-10.

14. Hintschich C. Correction of entropion and ectropion. Dev Ophthalmol. 2008;41:85-102

15. Bashour M, Harvey J. Causes of involutional ectropion and entropion-age-related tarsal changes are the key. Ophthal Plast Reconstr Surg. 2000;16(2):131-41.

16. Heimmel MR, Enzer YR, Hofmann RJ. Entropion-ectropion: the influence of axial globe projection on lower eyelid malposition. Ophthal Plast Reconstr Surg. 2009;25(1):7-9.

17. Rawlings AV. Ethnic skin types: are there differences in skin structure and function? Int J Cosmet Sci. 2006;28(2):79-93.

18. Diridollou S, De Rigal J, Querleux B, Leroy F, Holloway Barbosa V. Comparative study of the hydration of the stratum corneum between four ethnic groups: influence of age. Int J Dermatol. 2007;46 Suppl 1:11-4

19. Bae JB, Park WC. Histopathologic Characteristics of Conjunctivochalasis. Jhe Korean Ophthalmol Soc. 2013;54(8):1165-74. 
20. Kase S, Noda M, Yoshikawa H, Yamamoto T, Ishijima K, Ishida S. Oxidative stress in the levator aponeurosis in Asian involutional blepharoptosis. Ophthal Plast Reconstr Surg. 2014;30(4):290-4.

21. Stefanyszyn MA, Hidayat AA, Flanagan JC. The histopathology of involutional ectropion. Ophthalmology. 1985;92(1):120-7.

22. Kocaoglu FA, Katircioglu YA, Tok OY, Pulat H, Ornek F. The histopathology of involutional ectropion and entropion. Can J Ophthalmol. 2009;44(6):677-9.

23. Scheepers MA, Singh R, Ng J, Zuercher D, Gibson A, Bunce C, et al. A randomized controlled trial comparing everting sutures with everting sutures and a lateral tarsal strip for involutional entropion. Ophthalmology. 2010;117(2):352-5.

24. Collin JR, Rathbun JE. Involutional entropion: a review with evaluation of a procedure Arch Ophthalmol. 1978;96(6):1058-64.

25. Barnes J, Bunce C, Olver JM. Simple effective surgery for involutional entropion suitable for the general ophthalmologist. Ophthalmology. 2006;113(1):92-6.

26. Danks JJ, Rose GE. Involutional lower lid entropion: to shorten or not to shorten? Ophthalmology. 1998;105(11):2065-7

27. Damasceno RW, Heindl LM, Hofmann-Rummelt C, Belfort R Jr, Schlötzer-Schrehardt U, Kruse $\mathrm{FE}$, et al. Pathogenesis of involutional ectropion and entropion: the involvement of matrix metalloproteinases in elastic fiber degradation. Orbit. 2011;30(3):132-9.

28. Netland PA, Sugrue SP, Albert DM, Shore JW. Histopathologic features of the floppy eyelid syndrome: involvement of tarsal elastin. Ophthalmology. 1994;101(1):174-81.

29. Debelle L, Tamburro A. Elastin: molecular description and function. Int J Biochem Cel Biol. 1999:31(2):261-72

30. Schlötzer-Schrehardt U, Stojkovic M, Hofmann-Rummelt C, Cursiefen C, Kruse FE, Holbach LM. The pathogenesis of floppy eyelid syndrome: involvement of matrix metalloproteinases in elastic fiber degradation. Ophthalmology. 2005;112(4):694-704

31. Alfonso-Jaume MA, Bergman MR, Mahimkar R, Cheng S, Jin ZQ, Karliner JS, et al Cardiac ischemia-reperfusion injury induces matrix metalloproteinase-2 expression through the AP-1 components FosB and JunB. Am J Physiol Heart Circ Physiol. 2006; 291(4):H1838-H46

32. Cheung PY, Sawicki G, Wozniak M, Wang W, Radomski MW, Schulz R. Matrix metalloproteinase-2 contributes to ischemia-reperfusion injury in the heart. Circulation. 2000;101(15):1833-9.

33. Ghomrasseni S, Dridi M, Gogly B, Bonnefoix M, Vabres P, Venencie PY, et al. Anetoderma: an altered balance between metalloproteinases and tissue inhibitors of metalloproteinases. Am J Dermatol. 2002;24(2):118-29.
34. Patroi I, Annessi G, Girolomoni G. Mid-dermal elastolysis: a clinical, histologic, and immunohistochemical study of 11 patients. J Am Acad Dermatol. 2003:48(6):846-51.

35. Prajapati RT, Eastwood M, Brown RA. Duration and orientation of mechanical loads determine fibroblast cyto-mechanical activation: monitored by protease release. Wound Repair Regen. 2000;8(3):238-46.

36. Lindsey M, Wedin K, Brown MD, Keller C, Evans AJ, Smolen J, et al. Matrix-dependent mechanism of neutrophil-mediated release and activation of matrix metalloproteinase 9 in myocardial ischemia/reperfusion. Circulation. 2001;103(17):2181-7.

37. Swartz M, Tschumperlin D, Kamm R, Drazen J. Mechanical stress is communicated between different cell types to elicit matrix remodeling. Proc Natl Acad Sci USA. 2001; 98(11):6180-5.

38. Spinale FG. Myocardial matrix remodeling and the matrix metalloproteinases: influence on cardiac form and function. Physiol Rev. 2007:87(4):1285-342.

39. Damasceno RW, Osaki MH, Dantas PE, Belfort R Jr. Involutional ectropion and entropion: clinicopathologic correlation between horizontal eyelid laxity and eyelid extracellular matrix. Ophthal Plast Reconstr Surg. 2011;27(5):321-6.

40. Sisler H, Labay G, Finlay J. Senile ectropion and entropion: a comparative histopathological study. Ann Ophthalmol. 1976;8(3):319-22

41. Marshall JA, Valenzuela AA, Strutton GM, Sullivan TJ. Anterior lamella actinic changes as a factor in involutional eyelid malposition. Ophthal Plast Reconstr Surg. 2006;22(3): $192-4$

42. Imayama S, Braverman I. A hypothetical explanation for the aging of skin. Chronologic alteration of the three-dimensional arrangement of collagen and elastic fibers in connective tissue. Am J Pathol. 1989;134(5):1019.

43. Varani J, Dame MK, Rittie L, Fligiel SE, Kang S, Fisher GJ, et al. Decreased collagen production in chronologically aged skin: roles of age-dependent alteration in fibroblast function and defective mechanical stimulation. Am J Pathol. 2006;168(6):1861-8.

44. Baumann L. Skin ageing and its treatment. J Pathol. 2007;211(2):241-51.

45. Uitto J. Understanding premature skin aging. N Engl J Med. 1997;337(20):1463-5. Comment on: N Engl J Med. 1997;337(20):1419-28

46. Tyers A. Aging and the ocular adnexa: a review. J R Soc Med. 1982;75(11):900-2.

47. Heindl LM. Eyelids. In: Naumann GO, Kruse FE, editor. Applied pathology of ophthalmic microsurgeon. Berlin: Springer; 2008. p.30-44.

48. Liesegang TJ, Cantor LB. Ocular malposition and involutional changes. In: American Academy of Ophthalmology. Orbit eyelids and lacrimal system. San Francisco, CA: American Academy of Ophthalmology; 2007. p.236-7.

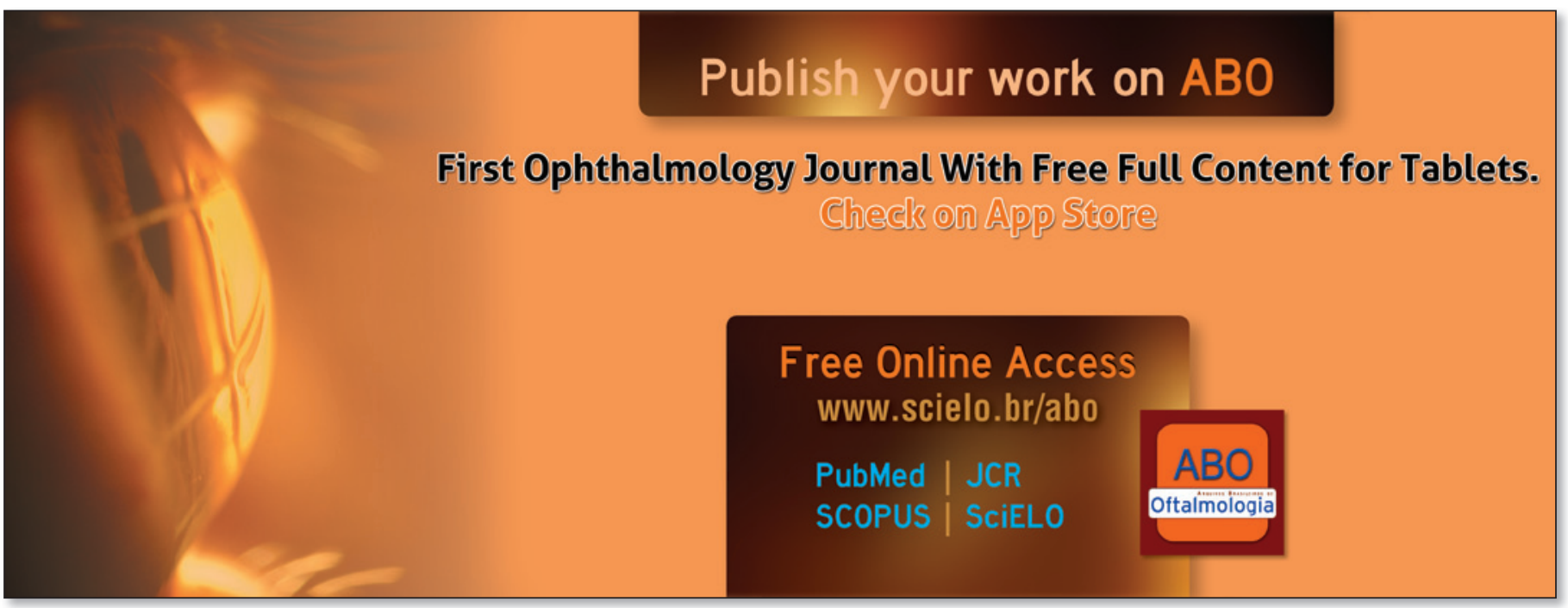

